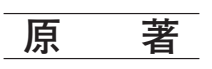

\title{
上半規管裂隙症候群例
}

\author{
清水 志乃 $^{1)} \cdot$ 西口 達治 $^{1)} \cdot$ 安岡公美子 ${ }^{122} \cdot$ 大江祐一郎 ${ }^{1)} \cdot$ 神前 英明 ${ }^{1)}$ \\ 清水 猛史 ${ }^{1)}$
}

\section{A case of superior canal dehiscence syndrome}

\author{
Shino Shimizu ${ }^{1)}$, Tatsuji Nishiguchi ${ }^{1)}$, Kumiko Yasuoka ${ }^{12)}$, Yuichiro Oe ${ }^{1)}$, \\ Hideaki Kouzaki ${ }^{1)}$, Takeshi Shimizu ${ }^{1}$ \\ ${ }^{1)}$ Department of Otorhinolaryngology, Shiga University of Medical Science \\ ${ }^{2)}$ Department of Otorhinolaryngology, Hino Memorial Hospital
}

\begin{abstract}
Superior canal dehiscence syndrome (SCDS) was first described by Minor et al. in 1998 . Symptoms associated with SCDS include conductive hearing loss and vertiginous symptoms in the setting of loud noises (Tullio phenomenon) or during the Valsalva maneuver. The condition is caused by a bony defect in the roof of the superior semicircular canal. We encountered the case of a 46-year-old male patient with SCDS who presented with pressure- and loud soundinduced vertigo. The patient was diagnosed as having SCDS based on pressure- and soundinduced occurrence of nystagmus confirmed by video-oculography (VOG). We also investigated the prevalence of superior semicircular canal dehiscence at our hospital using our CT scan database. The roof of the superior semicircular canal was classified into three types, normal, thin bony roof, and bony defect. Out of 1003 ears, 897 ears $(89.4 \%)$ were normal, 77 ears (7.7\%) had a thin bony roof, and 29 ears $(2.9 \%)$ showed a bony defect in the roof of the superior semicircular canal. Out of 25 patients (29 ears) with a bony defect, only one patient was diagnosed as having SCDS.
\end{abstract}

Key words: superior canal dehiscence syndrome, Tullio phenomenon, VOG, VEMP, CT

\section{緒言}

上半規管裂隙症候群 (Superior canal dehiscence syndrome, SCDS）は, 1998年にMinorらによっ て初めて報告された疾患で, 上半規管の骨迷路の中 頭蓋窩側の裂隙が，内耳において正円空，卵円空に 次ぐ第 3 の空になることにより，典型例では瘻孔症 状や音刺激によるめまい(Tullio 現象), 低音域の 伝音難聴が生じる ${ }^{1)}$ 。

\footnotetext{
1) 滋賀医科大学耳鼻咽喉科
}

2) 日野記念病院耳鼻咽喉科
今回，われわれが経験した上半規管裂隙症候群例 を提示し，当科で2016年 4 月から2019年 3 月に撮影 した内耳 CT 画像で観察された上半規管裂隙の頻度 を報告する。

症例：46歳男性

主訴：めまい

職業 : クリーニング店経営

現病歴：当科受診の 1 年前から, 頭部を動かして 視線を移動させた際に, 書類の文字から焦点がずれ ることに気づいた。眼科を受診したが異常所見は認 められなかった。半年前から, 力んだ時や重いもの 


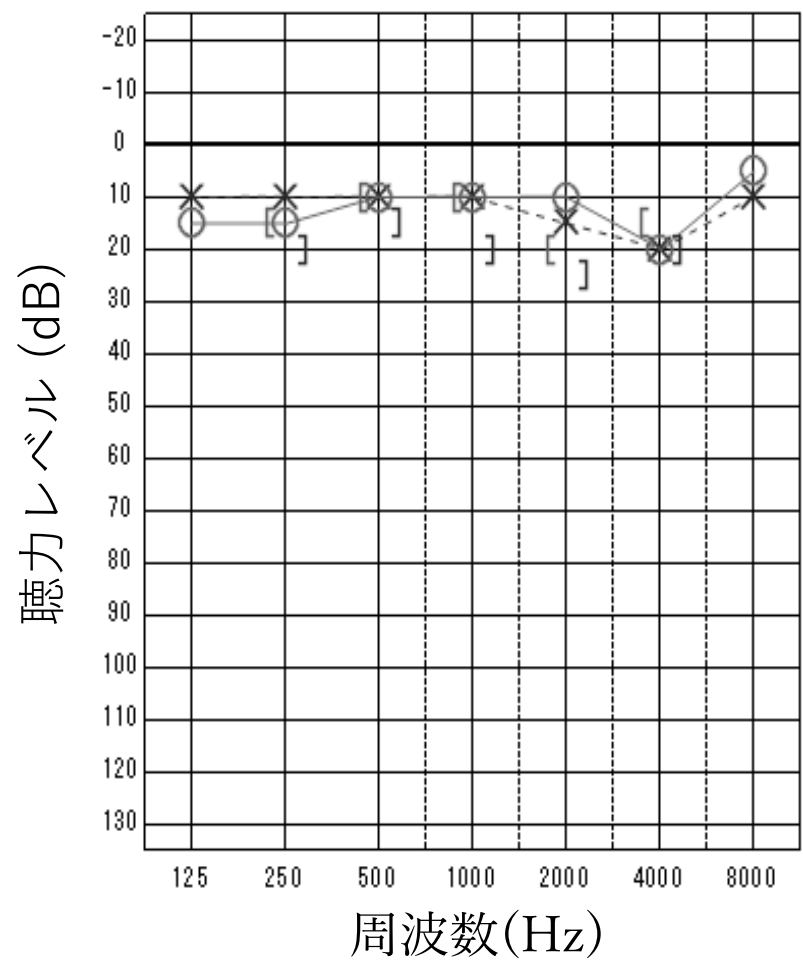

図 1 純音聴力検査

を持ち上げた時にめまいを感じるようになった。難 聴・耳鳴は認めなかった。脳神経外科を受診し, MRI 検查を受けたが異常所見は認められなかっ た。その後，ランニングや咳嗽時にもめまい感が出 現するようになり，精查目的で当科を紹介受診し た。

既往歴：特記すべきことなし

初診時現症：両側の外耳および鼓膜所見, 鼻腔, 咽頭, 頸部に異常を認めなかった。視力や温痛覚に 異常なく, 顔面の麻痺もなかった。指鼻指試験・手 回内回外試験は異常なく, ロンベルグ試験も陰性で あった。

標準純音聴力検査: 聴力レベルは 4 分法で, 右 10 $\mathrm{dB}$ ，左 $11.25 \mathrm{~dB}$ と正常であった（図 1 )。

平衡機能検査 : 自発眼振 ・注視眼振なし。頭位 頭位変換眼振も認められなかった。温度刺激検查は 両側とも半規管麻痺を認めなかった。Glottic Valsalva maneuver, Nose-pinched Valsalva maneuver, 外耳道の加圧, そして右耳気導純音刺激時の眼球運 動をそれぞれ眼球運動検査装置（yVOG-glass，第 一医科）で記録した。Glottic Valsalva maneuver で は回旋成分を含む眼球偏倚を認めた。加圧時には,
眼球はわずかに右向きかつ下眼瞼向きに偏倚し，大 きく反時計回りに回旋した。圧を開放すると眼位は 戻った（図 2 )。圧負荷を繰り返すと同様の眼球偏 倚が観察された。Nose-pinched Valsalva maneuver では，左向き上眼瞼向きにわずかに偏倚する傾向を 認め, 加圧時にゆるやかに時計回りに眼球が回旋 し，圧を開放すると眼位は元に戻った（図 3 )。右 外耳道の指による加圧では, 加圧時にわずかに右向 き反時計回り, 大きく下眼瞼向きの眼球偏倚があ り，圧を開放すると眼位は戻った（図 4)。Tullio 現象の検査として Sono-ocular testを行った。他の 報告に準じてオージオメーターを用いて $110 \mathrm{~dB}$ の 断続音を提示した ${ }^{2)}$ 。休憩をはさみながら $500 \mathrm{~Hz}$, 1,000 Hz，2,000 Hz，4,000 Hz の順に記録した。500 $\mathrm{Hz}$ 刺激が最も明瞭に刺激音に一致する眼球偏倚を 誘発した（図 5 )。 $500 \mathrm{~Hz}$ 刺激では，上眼瞼向きの 垂直成分の偏倚角度は第 1 音が最大で, 刺激を継続 すると減衰した。速度も同様に第 1 音が最大で, 刺 激を継続すると減衰した。また, 反時計回りの回旋 も刺激音に一致して記録された。 $500 \mathrm{~Hz}$ と $1,000 \mathrm{~Hz}$ 刺激時の垂直成分を比較した（図 6 )。第 1 音の上 眼瞼向きの眼球偏倚を比較すると, 偏倚角度は 500 $\mathrm{Hz}$ が $5.1 \mathrm{deg}, \quad 1,000 \mathrm{~Hz}$ が $2.8 \mathrm{deg}$, 偏倚速度は 500 $\mathrm{Hz}$ が $91.4 \mathrm{deg} / \mathrm{sec}, 1,000 \mathrm{~Hz}$ が $53.2 \mathrm{deg} / \mathrm{sec}$ であ り, $500 \mathrm{~Hz}$ のほうが大きく早い眼球偏倚を誘発し た。 $2,000 \mathrm{~Hz}$ 刺激でもわずかに垂直性眼球偏倚を認 めたがその偏倚角度は $1,000 \mathrm{~Hz}$ 刺激時よりさらに 小さく, 4,000 Hz 刺激では明らかな眼球偏倚は検出 されなかった（デー夕掲載なし）。頸部前庭誘発筋 電位検査 (Cervical vestibular evoked myogenic potential, cVEMP, 刺激音 $500 \mathrm{~Hz}$ 気導トーンバース 卜, 頻度 $5 \mathrm{~Hz}$ ) では右（患側）の反応は正常で, 左（健側）は反応不良を認め, 左右差を認めた（図 7 )。検者や胸鎖乳突筋の緊張方法を変更して 2 度 再検したが左の反応は不良であった。

画像検查：頭部 MRI 検査で頭蓋内・内耳・中耳 に異常は認めなかったが, 内耳 CT 検査の冠状断ス ライスにて両側上半規管の中頭蓋窩側の骨欠損が疑 われた（図 $8 \mathrm{~A})$ 。上半規管ループに沿った再構築 画像（Pöschl plane）で骨欠損部分を確認すると， 右上半規管に骨欠損があり（図 8 B)，左上半規管 には骨の菲薄化が認められた（図 8 C)。 


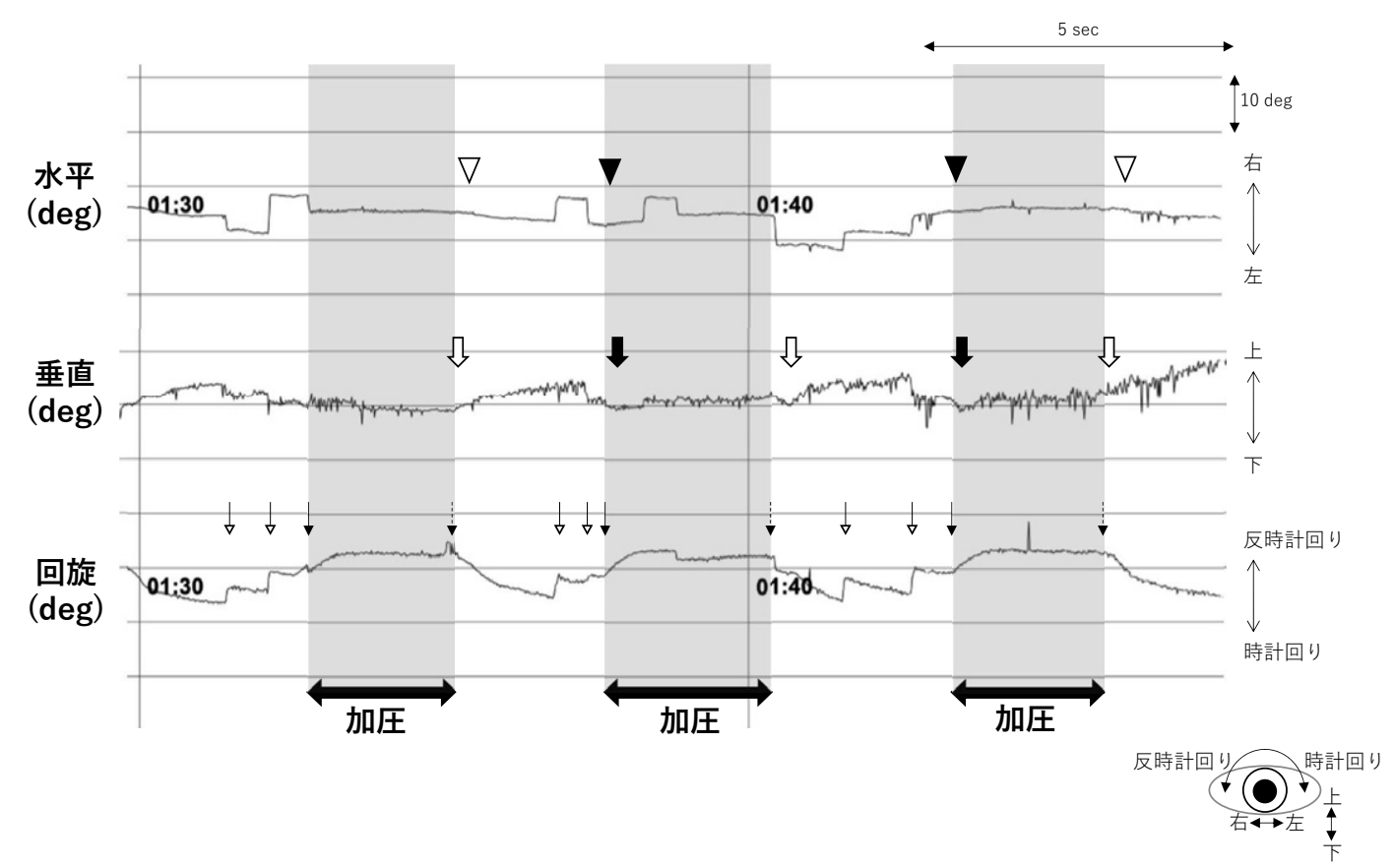

図2 Glottic Valsalva maneuver における眼球偏倚

水平成分は，加圧開始時（黒矢頭）から圧解放までの間に徐々にわずかに右向きに偏 倚し，圧を開放すると（白矢頭）ゆっくり戻った。垂直成分は，加圧初期に（黒太矢 印）下眼瞼向きにわずかに偏倚し，圧を開放すると(白太矢印) 徐々に上眼瞼向きに 偏倚して，その後正中に戻った。回旋成分は，加圧すると（黒矢印）反時計回りに回 旋してとどまり，圧を解放すると（破線矢印）逆の時計回りに大きく回旋し，その後 戻った。時計回りの回旋から戻る際に反時計回りかつ下眼瞼向きの右寄りまたは左寄 りの眼振が $1-2$ 打観察されることがあった（白矢印）。

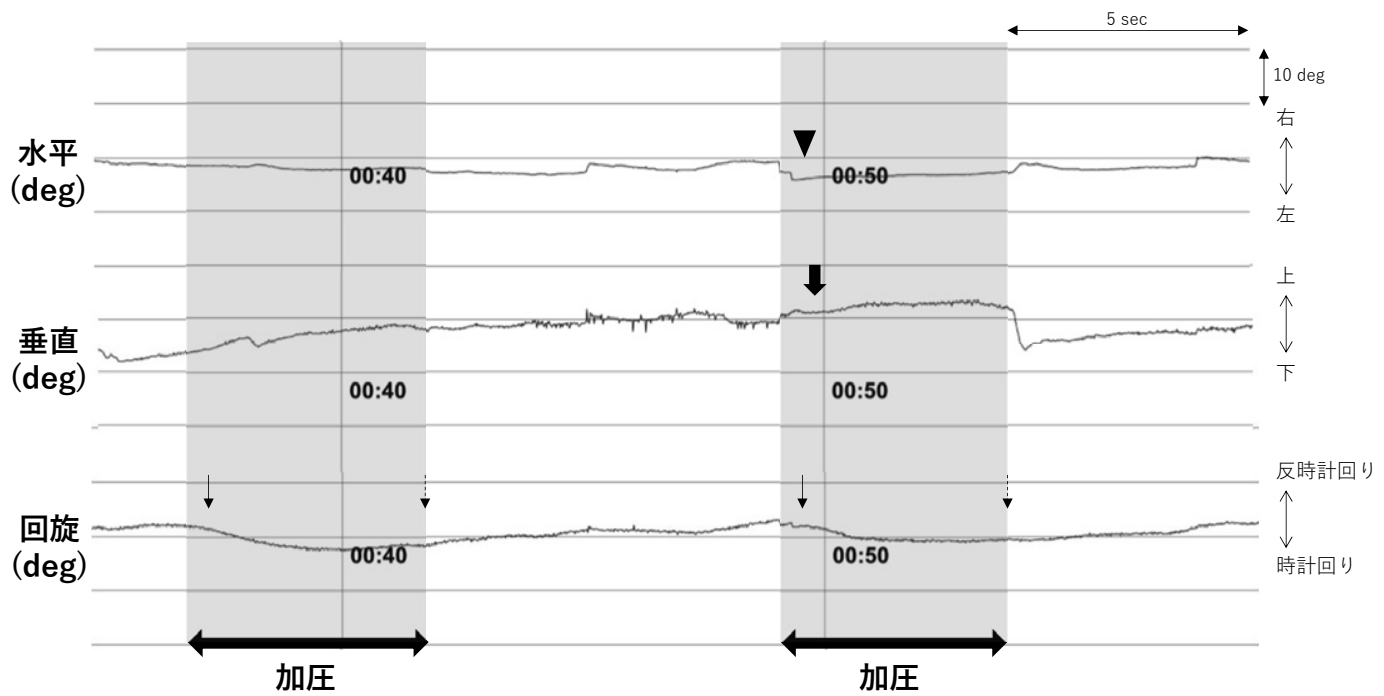

図3 Nose-pinched Valsalva maneuver における眼球偏倚

加圧時に左向き (黒矢頭)，上眼瞼向き（黒太矢印）に偏倚する傾向を認めた。回旋 成分は，加圧するとゆるやかに時計回りに（黒矢印）回旋してとどまり，圧を開放す ると(破線矢印) 反時計回りにゆっくり戻った。息こらえをした時点で Glottic Valsalva maneuverによる眼球偏倚が生じることがあり，安定したデー夕を得ることは難しか った。 


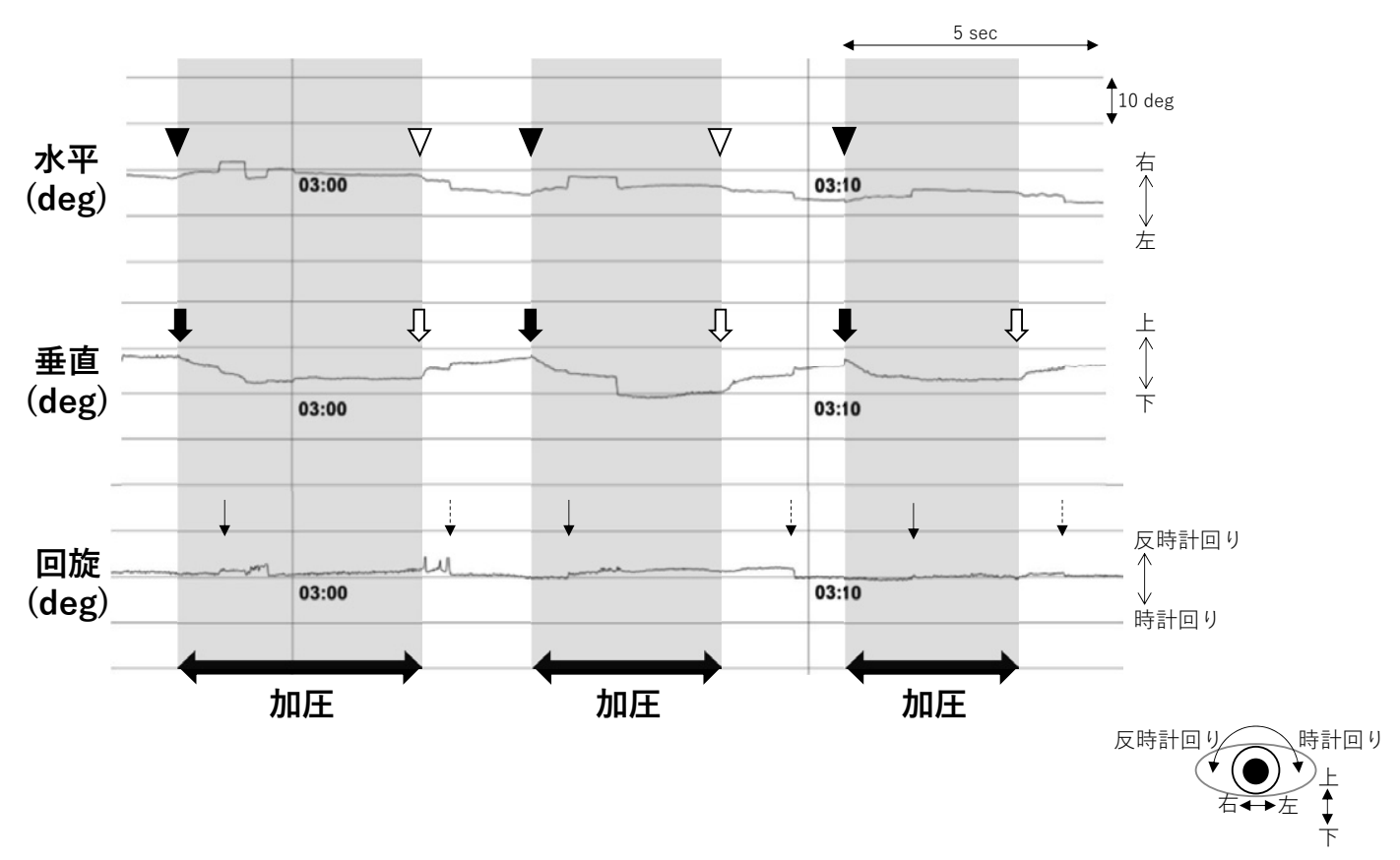

図4 右外耳道圧迫における眼球偏倚

水平成分は，加圧開始時（黒矢頭）からわずかに右向きに偏倚してとどまり，圧解放 時（白矢頭）に左向きに戻った。垂直成分は, 加圧開始時（黒太矢印）から徐々に下 眼瞼向きに偏倚してとどまり，圧を解放時すると（白太矢印）上眼瞼向きに戻った。 回旋成分は, 加圧開始から少し遅れて (黒矢印) 反時計回りにわずかに偏倚し, 圧を 開放すると少し遅れて（破線矢印）時計回りに戻った。垂直方向の偏倚が最も明瞭で あった。

治療経過：臨床症状，CT所見，そして圧および 音刺激時の眼球偏倚所見より, 右上半規管裂隙症候 群と診断した。経過中に環境音に対する聴覚過敏と それに伴って誘発される浮動感, 歩行時のステップ 音や自動車運転時の振動やエンジン音，大きく開口 した際や咀嚼時の体内音などでも誘発される浮動感 を自覚していることが分かった。保存的治療を希望 されたため, 右耳栓装用と右鼓膜チューブ留置を行 った。耳栓の装用により環境音刺激によるめまい誘 発は若干軽減した。右鼓膜チューブ留置では自覚症 状は改善せず，逆に鼓膜チューブ留置後に右耳閉 感・難聴の訴えがあり 2 力月後に抜去した。鼓膜チ ユーブ留置時に測定した聴力は純音聴力検査で正常 であった。右耳栓装用のみで経過観察していたが, 耳栓装用に伴う外耳の圧迫が誘発する浮動感が不快 であるため耳栓装用も中止し，経過観察中である。

\section{CT 画像による上半規管裂隙の検討}

目的と方法：上半規管裂隙症候群は比較的欧米人 に多いが，わが国での CTに打ける上半規管裂隙の 頻度を検討した報告はほとんどない。そこで，2016
年 4 月 1 日から 2019 年 3 月 31 日の 3 年間に当科で内 耳 CT 検査を受けた 508 名のうち, 内耳の冠状断 1 $\mathrm{mm}$ スライスで上半規管の評価の可能であった503 名, 1,003 耳 ( 0 歳から 88 歳, 平均年齢46.6歳, 男 性495耳，女性508耳）にお打生規管の中頭蓋窩 側の骨壁の形状について評価した。画像の評価は耳 鼻咽喉科専門医 2 名で行い, 骨壁が骨で完全に覆わ れているものを正常，骨壁が非常に薄いが欠損はし ていないものを菲薄化，骨壁が完全に欠損している ものを欠損として 3 つに分類した。本研究は滋賀医 科大学倫理審査委員会の了承を得た後（R 2019173), 滋賀医科大学ホームページ上でオプトアウト を行った。検定にはSPSS ver. 25（IBM）を用い た。 $\mathrm{p}<0.05$ をもって有意差ありとした。

結果: 1,003 耳のうち, 897 耳 $(89.4 \%)$ が正 常，77耳 (7.7\%) が菲薄化，そして 29 耳 (2.9\%) に欠損つまり上半規管裂隙を認めた（図 9)。男女 間の比較では, 有意な差は認めなかった（図 $10 \mathrm{~A}$, $\mathrm{p}=0.923, \chi 2$ 乗検定)。男性の 495 耳 中 447 耳 (90.3\%) が正常, 34耳（6.9\%）が菲薄化, そして 


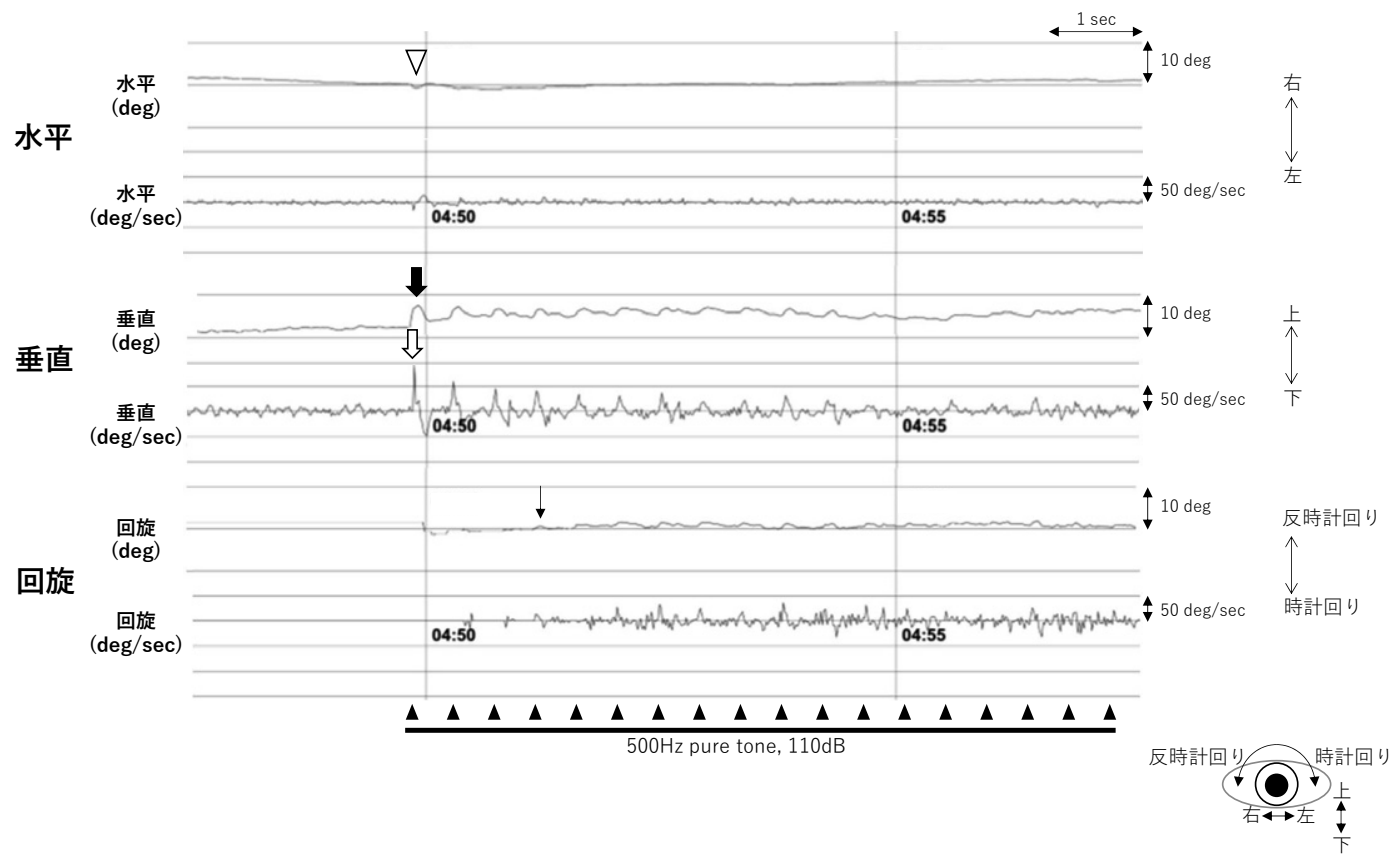

図5 Tullio 現象における眼球偏倚 $(500 \mathrm{~Hz}$ pure tone, $110 \mathrm{~dB}$ )

水平成分は，第 1 音（白矢頭）でわずかに左に偏倚している。垂直成分は，刺激音に一 致した上眼瞼向きの眼球偏倚が記録され，第 1 音による刺激が偏倚角度 (黒太矢印), 速度（白太矢印）共に最大で，刺激を継続すると徐々に減衰した。回旋成分は，第 3 音 までは記録できていないが，第 4 音（黒矢印）以降で刺激音に一致した反時計回りの眼 球偏倚が記録された。

A

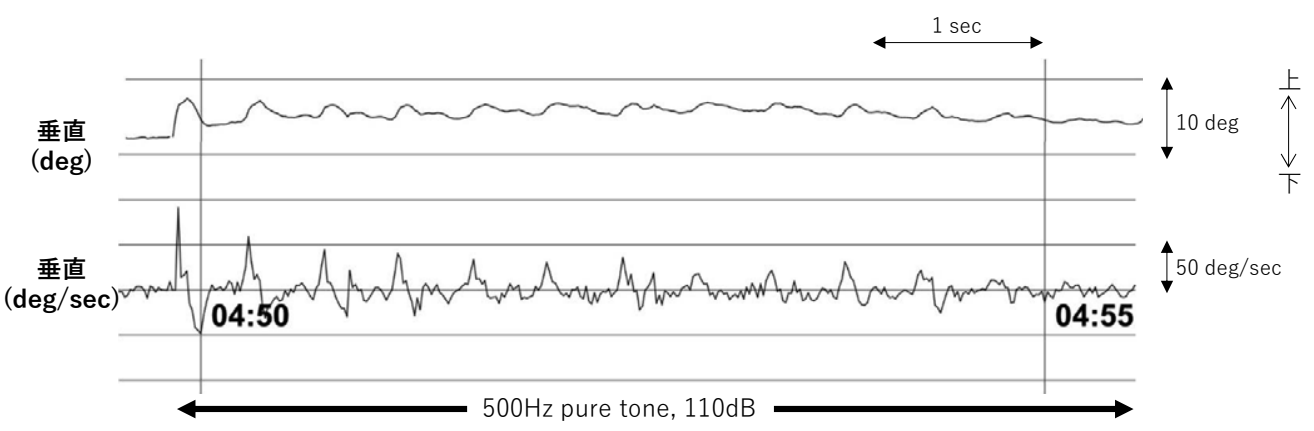

$\mathrm{B}$

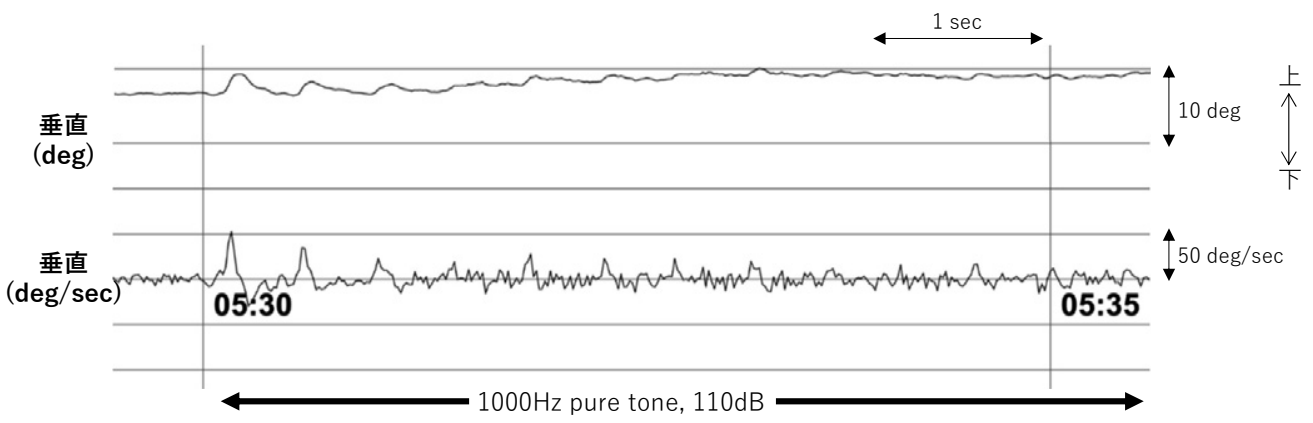

図6 Tullio 現象の刺激音周波数による比較（A：500 Hz，B：1,000 Hz）

$500 \mathrm{~Hz}$ 刺激, $1,000 \mathrm{~Hz}$ 刺激共に上眼瞼向きの垂直成分の偏倚角度は第 1 音が最大で 刺激を継続すると徐々に減衰した。偏倚速度も第 1 音が最大で刺激を継続すると徐々 に減衰した。第 1 音の上眼瞼向きの眼球偏倚について $500 \mathrm{~Hz}$ 刺激と $1,000 \mathrm{~Hz}$ 刺激を 比較すると，偏倚角度は $500 \mathrm{~Hz}$ が $5.1 \mathrm{deg}, 1,000 \mathrm{~Hz}$ が $2.8 \mathrm{deg}$, 偏倚速度は $500 \mathrm{~Hz}$ が $91.4 \mathrm{deg} / \mathrm{sec}, 1,000 \mathrm{~Hz}$ が $53.2 \mathrm{deg} / \mathrm{sec}$ であり，500 Hz 刺激のほうが大きく早い眼 球偏倚を誘発した。 


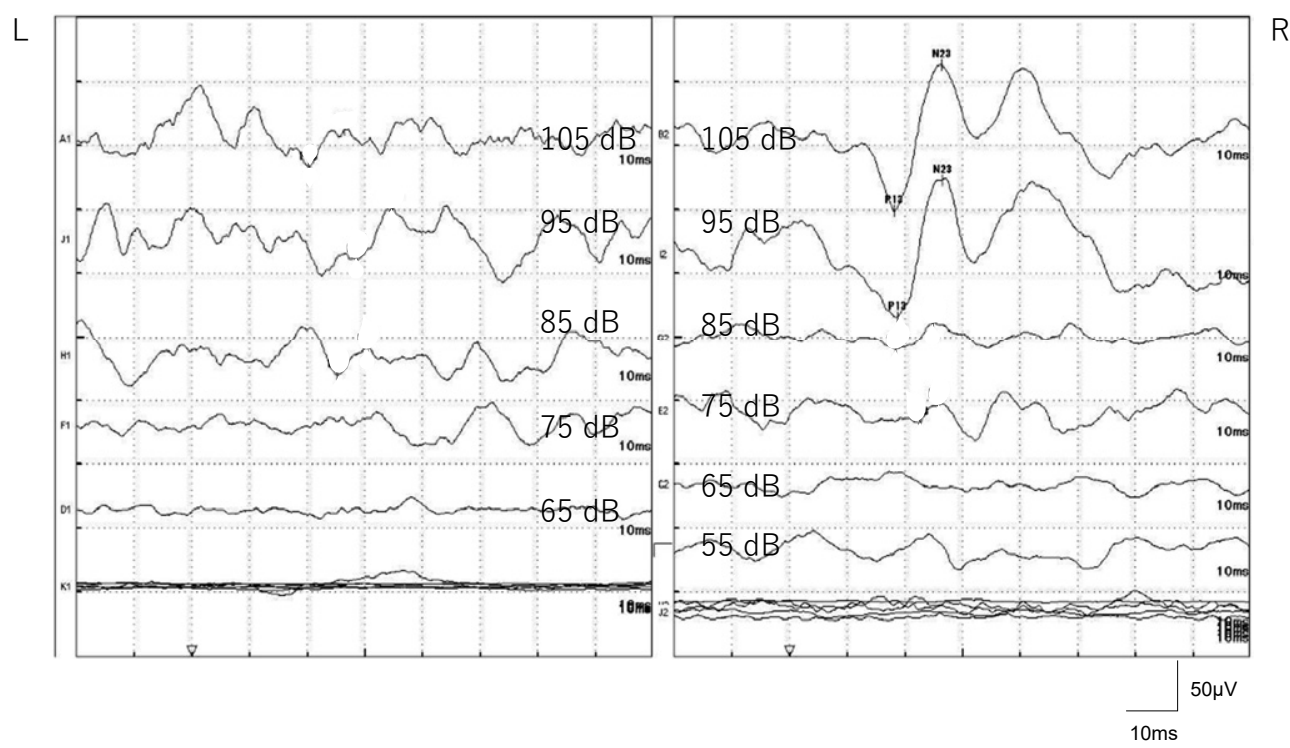

图7 cVEMP（刺激音 $500 \mathrm{~Hz}$ 気導トーンバースト, 頻度 $5 \mathrm{~Hz}$ )

右（患側）の反応は正常で, 左（健側）は反応不良を認め, 左右差を認めた。

14 耳 $(2.8 \%)$ に欠損を認め，女性の508耳中 455 耳 (89.6\%) が正常, 38 耳 $(7.5 \%)$ が菲薄化, そして $15 耳 （ 3.0 \%)$ に欠損を認めた。慢性中耳炎や真珠 腫性中耳炎などの慢性炎症の有無で比較すると，有 意な差を認めた（図 $10 \mathrm{~B}, \mathrm{p}=0.008 ， \chi 2$ 乗検定）。 慢性炎症のない 665 耳中 609 耳 $(91.6 \%)$ が正常, 40 耳 $(6.0 \%)$ が菲薄化，そして 16 耳 $(2.4 \%)$ に欠損 を認め，慢性炎症のある338耳中 288 耳 $(85.2 \%)$ が 正常, 37耳 (10.9\%) が菲薄化, そして13耳 （3.8\%）に久損を認めた。年代別の比較では年代間 で差は見られなかった（図 $11, p=0.139 ， \chi 2$ 乗検 定)。

\section{考察}

われわれが経験した上半規管裂隙症候群例の主訴 は腹圧がかかった際や強大音聴取時のめまいであっ た。本症候群患者の訴える症状は，(1)持続する浮動 感 $(51 \%)$, (2)音で誘発されるめまい $(42.7 \%)$, (3) 自声強聴 (42.5\%), (4)難聴 $(39.9 \%)$, (5)圧で誘発

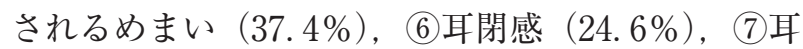
鳴 (17.2\%)，8拍動性耳鳴 (13.7\%) の順で多い が，必ずしもすべての症例が特徴的な症状を訴える わけではない3)。頻度は低いが特徵的な症状とし て, 環境音に加えて体内の音に対する聴覚過敏と浮 動感の誘発がある。本例ではさまざまな環境音に対 する聴覚過敏とそれによって誘発される浮動感以外
に，歩行時のステップ音や自動車運転時の振動やエ ンジン音, 開口・咀嚼時の体内音などで誘発される 浮動感も自覚していることが詳細な問診後に明らか になった。

本症候群の正式な診断基準はまだ確立されていな いが, 上記のような臨床症状に加えて㾇孔症状や低 音域の伝音難聴，VEMPの反応閾值の低下と振幅 の増大などで上半規管裂隙症候群を疑い, CT 検査 で裂隙を確認したうえで，圧刺激や強大音刺激によ る眼振が確認できれば診断が確実である4。特に瘦 孔症状が存在する場合は, CT 検查の際に上半規管 裂隙の存在にも注意して読影することが大切であ る。本症例では, 臨床症状と CT 画像で本症候群を 強く疑い，その後の検查で圧負荷時または音刺激時 の眼振所見を確認して診断に至った。CT 単独では 診断できないことから, 診断のための検査を追加し たが，特徴的な所見を他覚的にとらえることに難啮 した。当初Valsalva maneuverは一度の加圧で観察 していたために眼球偏倚を見逃しており，加圧と開 放を反復して赤外線 CCD カメラで複数回録画する ことでとらえることができた。外耳の加圧は，ポリ ッツェル球よりも自身の指による圧迫の反復のほう が容易に眼球偏倚を誘発した。Tullio 現象について も，当初はオージオメーターによる刺激を用いなか ったため音刺激による垂直性眼球偏倚を見逃してい 

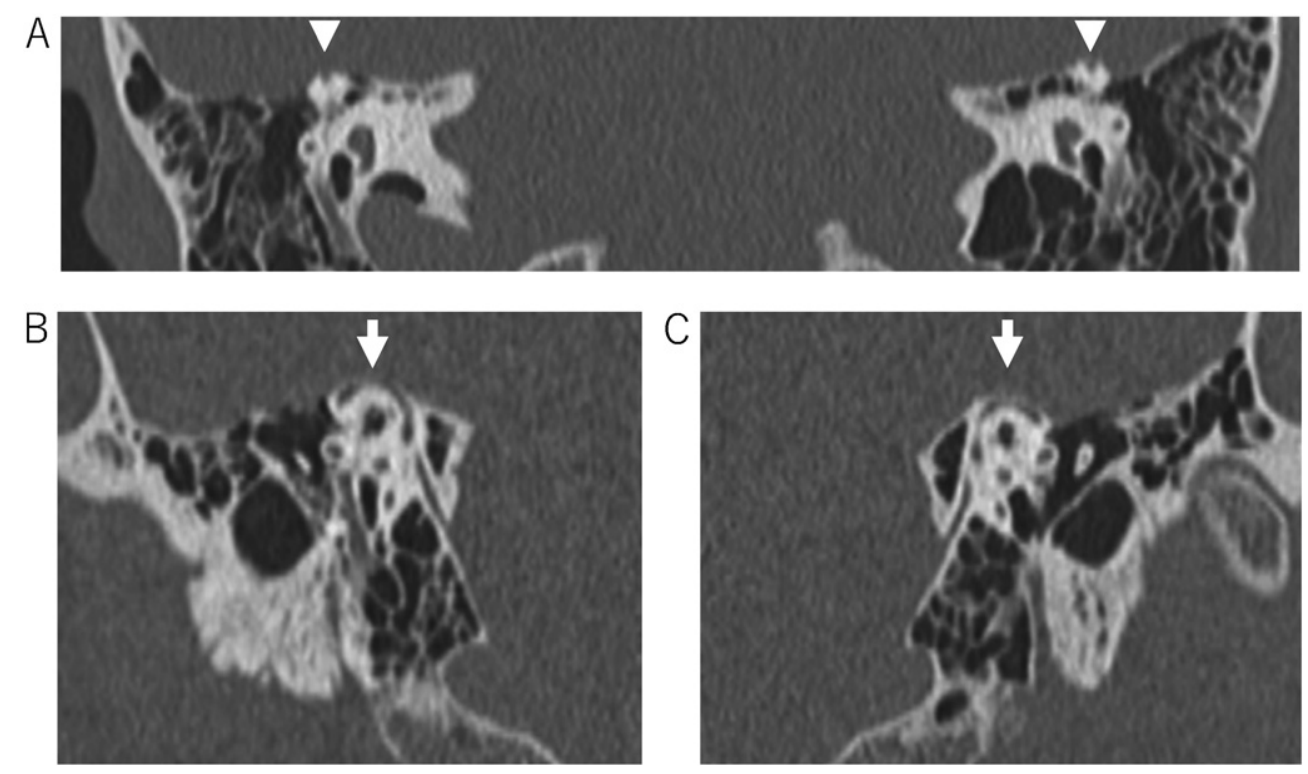

図8 提示症例の内耳 CT 所見

A : 冠状断 $1 \mathrm{~mm}$ スライス画像では両側上半規管の中頭蓋窩側の骨壁が久損して いる。

B : 右 Pöschl plane では骨壁欠損を認める。

C : 左 Pöschl plane では薄い骨壁を認める。

\section{欠損29耳 $(2.9 \%)$}

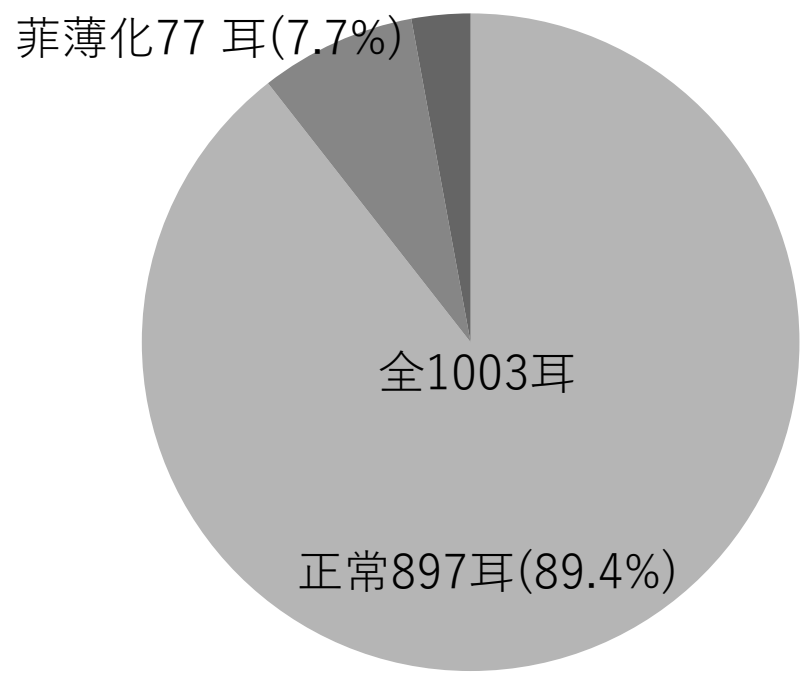

図9冠状断 $1 \mathrm{~mm}$ スライス CT 画像での上半規管 の評価

た。

右上半規管裂隙症候群では Glottic Valsalva maneuverで, 圧負荷をかけると胸腔内圧の上昇から 頭蓋内圧の上昇が生じ, その圧は裂隙部から上半規 管膨大部に伝わり上半規管膨大部が負に刺激され,
下眼瞼向き反時計回りに眼球偏倚が誘発される2)。 本症例でも同様の眼球偏倚が観察された。Nosepinched Valsalva maneuver では Glottic Valsalva maneuver で観察されたものとは逆向きの上眼瞼向き 時計回りの眼球偏倚が加圧時に観察された。圧負荷 によって耳管経由で中耳圧の上昇が生じ，その圧は 内耳空経由で反膨大部リンパ流を生じることで膨大 部が正に刺激されるためとされている2)。一方，外 耳道圧迫による不快感は, 有効であった耳栓装用を 止めるほど自覚症状が強かったため, 大きな眼球偏 倚を予想していた。実際に記録された右外耳道圧迫 による眼球偏倚は，水平回旋成分は少なく下眼瞼方 向への偏倚が主で, Nose-pinched Valsalva maneuverによる中耳加圧の眼球偏倚とは方向が逆転して おり，Glottic Valsalva maneuverによる眼球偏倚と 同方向であった。加圧部位が外耳か中耳かによって 頭部の偏倚方向が逆転することは過去にも報告され ている5)。外耳または中耳を加圧すると，中耳圧は 上昇し，その圧は卵円空または正円空を介して内耳 に伝播する ${ }^{6)}$ 。外耳道の圧迫による中耳圧の上昇時 には鼓膜が中耳側に内陥し直接卵円空を介して圧力 を伝達することがわかっているが, Nose-pinched 
A

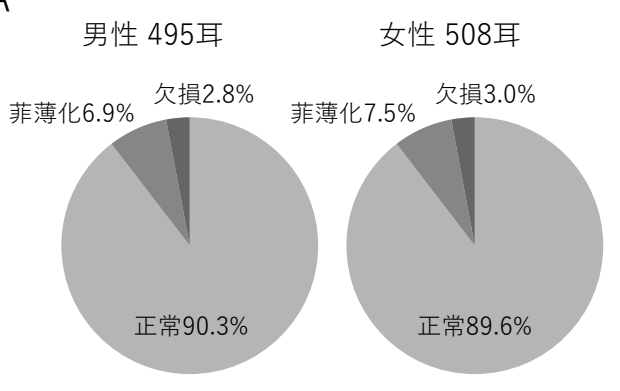

B

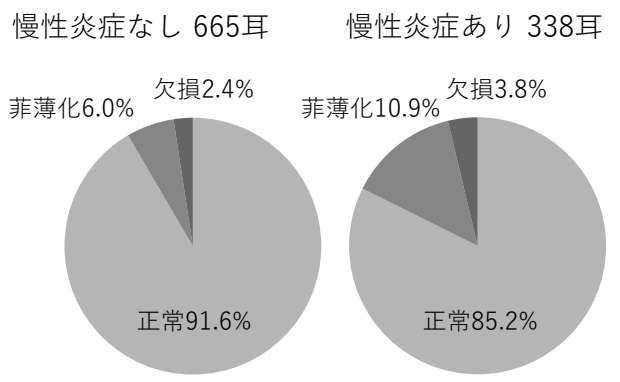

図10 冠状断 $1 \mathrm{~mm}$ スライス CT 画像での上半規管の評価 A：男女間では有意な差は認めなかった。 $\mathrm{p}=0.923$

$\mathrm{B} ：$ 慢性炎症の有無による比較では有意な差を認めた。 $\mathrm{p}=0.008$

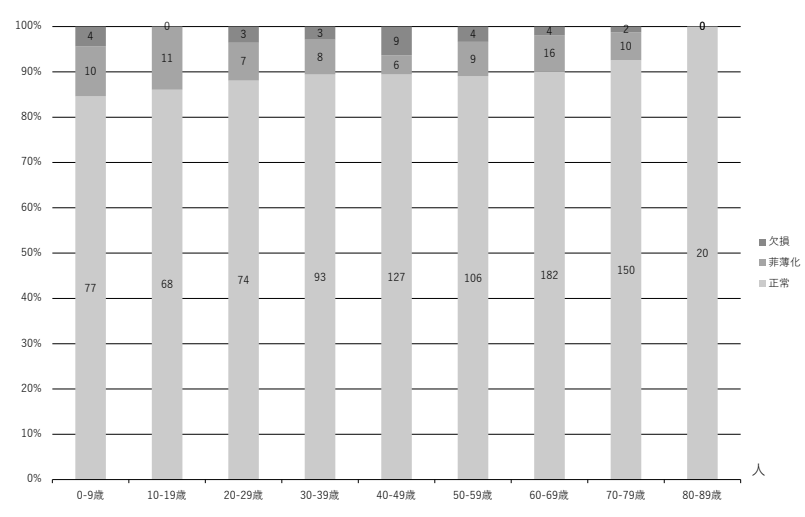

図11 冠状断 $1 \mathrm{~mm}$ スライス CT 画像での上半規管 の評価（年齢による比較）

年代間で有意差を認めなかった。 $\mathrm{p}=0.139$

Valsalva maneuverによる中耳圧の上昇時には逆に 鼓膜が外耳道側に膨隆するため，おそらく卵円空を 介した圧の伝達は変化する。結果として同じ中耳圧 の上昇でも，続いて上昇した内耳圧の上半規管への 伝播経路や耳石器への圧負荷が変わることによっ て, 外耳道圧迫時と Nose-pinched Valsalva maneuver 時で出現する眼球偏倚が変化するのではないか と考えている。次に, 音刺激による眼振については オージオメーターを用いた $110 \mathrm{~dB}$ の刺激を用い, 回旋成分も含めて詳細を記録することができた。 Sono-ocular testでは, これまでに報告されている ように $500 \mathrm{~Hz}$ と $1,000 \mathrm{~Hz}$ で明瞭な上眼瞼向きの眼 球偏倚が認められた7)。500 Hzの上眼瞼向きの垂直 成分の偏倚角度と速度は第 1 音が最大で, 刺激を継 続すると減衰した。この結果は環境音やステップ音 が持続する場合, 最初の刺激が最も強くめまいを誘
発するという本症例の訴えと一致した。具体的に は, ランニング開始直後はめまい感が非常に強いも のの, しばらく走行するとめまい感が減弱し走行が 可能になるとのことであった。上半規管裂隙症候群 で観察される Tullio 現象は，音響刺激が裂隙のある 上半規管側で外リンパ液を振動させ, 続いて生じた 内リンパ液の動きが耳石器や半規管膨大部を刺激 し，その結果生じる眼球偏倚である。しかし，その 詳細なメカニズムについてはいまだに不明な点が多 ( ${ }^{8) 99}$ 。本症候群では眼球運動や咀嚼に伴う筋肉の音 がめまいを誘発することがあるが3)，本症例は咀嚼 時のめまい感を訴えていた。受診 1 年前から自覚し ていた頭部の捻転時に生じる焦点のずれは，捻転に 伴う筋肉の音が眼球偏倚を誘発していた可能性があ る。一方, 低音域の伝音難聴も上半規管裂隙症候群 に特徵的な所見で, A-B gap の最大值は裂隙の長径 に相関することが報告されている ${ }^{10)}$ 。本症例では聴 力に左右差はなく A-B gap は認めなかったことか ら，裂隙のサイズが小さい可能性がある。さらに， cVEMP の反応閾值の低下と振幅の増大も上半規管 裂隙症候群に特徵的であるが, 本症例では健側の反 応不良を認めるのみで患側の右の反応は正常範囲で あった。胸鎖乳突筋緊張の方法を変えるなどして複 数回の再検を行ったが健側の反応不良は変わらず, その原因は不明である。cVEMPより ocular VEMP (oVEMP) が上半規管裂隙症候群で感度・特異度の 高い結果が期待できる可能性があり, OVEMP も測 定すべきであったと反省している11)。

治療は外科的治療と保存的治療に分けられ, 外科 的治療は側頭開頭あるいは乳突洞経由で上半規管を 
充填する方法（plugging）と裂隙部を被覆する方法

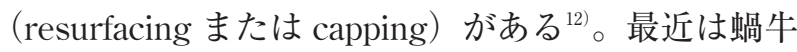
空小窩を閉鎖する方法 (round window reinforcement）も有効とする報告がある ${ }^{1314)}$ 。保存的に経過 を見た場合の長期的な予後についてのまとまった報 告はないが，手術治療を行っても術後に聴力が改善 されない症例があり，長期の圧刺激が徐々に内耳に 不可逆的な障害を与える可能性も示唆され, 聴力の 変化に注意しつつ経過観察していく必要がある ${ }^{15)}$ 。 本症例は根本的な外科的治療を希望されなかったた め, 右耳栓装用と右鼓膜チューブ留置術を行った。 耳栓装用は外部の音響を遮断することで，ある程度 の効果は認めたが, 内部の音に対して効果がなく, 耳栓は装用に伴う外耳の圧迫がめまいを誘発するた め装用を中止した。また，中耳腔の圧力を開放する ことを目的に鼓膜チューブを留置したが 2 力月ほど で抜去した。鼓膜チューブを抜去した理由はめまい 症状の改善に大きな効果がなく, 右耳閉感と難聴を 訴えたためであった。Nose-pinched Valsalva maneuver や右外耳道の加圧でもめまいの自覚があり 眼球偏倚も観察されたが, glottic Valsalva maneuver や音刺激ほどの強いめまいを誘発していなかったた め鼓膜チューブ留置の効果が限定的であった可能性 がある。また，チューブ留置によって右耳閉感と難 聴を自覚した原因として, 鼓膜チューブ留置そのも のが鼓膜の伝音特性そのものを変化させたことが考 えられる。鼓膜チューブを介して外耳道と鼓室の間 に通気があるため鼓膜の表裏の圧力差が小さくな り, 鼓膜振幅が減少し特に低周波数で聴力低下がみ られる可能性がある ${ }^{16)}$ 。

本邦では2003年に初めて上半規管裂隙症候群症例

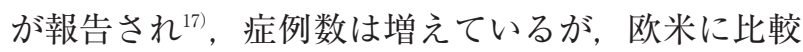
して有病率は低いと考えられている。しかし，これ までに本邦での有病率について報告した論文はな い。今回の検討では, 冠状断 $1 \mathrm{~mm}$ スライス CT 画 像で1,003耳中29耳（2.9\%）に骨壁欠損を認めた。 CT 画像を用いて本邦での上半規管裂隙の頻度を検 討した報告した論文が 1 編あり，耳鼻咽喉科受診患 者の 164 耳中 5 耳 $(3 \%)$ に C 画像上の骨壁欠損 を認め ${ }^{18)}$ ，われわれの今回の結果とほぼ一致する。 欧米の報告では, 冠状断 $1 \mathrm{~mm}$ スライス CT 画像で $9 \%$ の患者が骨壁欠損と診断され, 本邦と比較して
CT 画像上で骨壁欠損と診断される割合が高い ${ }^{199}$ 。 しかし，CT 上で $9 \%$ の骨壁欠損が確認される欧米 であっても，側頭骨の剖検例で実際に骨壁欠損が確 認されるのは剖検例全体の $0.5 \%$ であったと報告さ れ，CT 画像で診断された割合の更に 20 分の 1 程度 である ${ }^{20)}$ 。今回の検討に当てはめると, 同じ冠状断 $1 \mathrm{~mm}$ スライス CT 画像で 1,003 耳中 29 耳 $2.9 \%$ に骨 壁欠損が疑われても，実際に骨壁が欠損しているの は計算上 $0.17 \%$ ，つまり 1.7 耳であり，上半規管裂 隙症候群を発症する数はさらに少数であろうと予想 された。実際に上半規管裂隙症候群と診断されたの は 1,003 耳中本例 1 耳のみであった。症状から本症 候群を疑ったときにCT 画像は欠かせないが, 裂隙 の有無を冠状断 CT で正確に判断することは困難で あることが分かった。冠状断 CT での疑い症例すべ てに Pöschl planeの再構築を依頼することも現実 的でないことから, 症状と検查結果から強く疑われ る症例についてのみ Pöschl plane で確認するのが 良いと思われた。

上半規管の裂隙形成が先天的なものか後天的なも のかについてさまざま議論されてきた。菲薄化と骨 欠損の比率が加齢とともに増加し, 後天的な要素の 影響を指摘した報告もある ${ }^{2122)}$ 。しかし，この疾患 が認知されてから 20 年が経過し, 現在では上半規管 裂隙の形成は先天的なものであるとする意見が主流 になっている ${ }^{12)}$ 。欧米においては出生後から乳幼児 期の上半規管裂隙や菲薄化はそれほど珍しいもので はなく，10歳ころまでに徐々に骨化が進み裂隙が消 失することがわかってきた ${ }^{23) 25)}$ 。家族性あるいは症 候性の上半規管裂隙も報告されている ${ }^{26)}$ 28)。本邦で は小児期の上半規管の CT 所見についてまとまった 報告はないが，今回の結果では年代による比較にお いて統計学的な有意差は認めなかった。有意差はな いものの低年齢ほど欠損と菲薄化の割合が多く見え る部分に, 幼少期の不完全な骨化が影響している可 能性がある。慢性炎症の影響については，慢性中耳 炎や真珠腫性中耳炎があると上半規管の骨壁が菲薄 化している例が多かった。この結果は, 側頭骨の含 気が悪いほど上半規管を被う骨壁の厚さが薄いが, 上半規管裂隙の有無とは関連しないとする報告と一 致した ${ }^{29)}$ 。本症例では両耳とも炎症の既往はなく健 側にも菲薄化を認めることから先天的に右に骨欠 
損, 左に菲薄化があった可能性が高い。一方，上半 規管裂隙症候群の発症の契機として, 全体の 4 分の 1 は頭部外傷や Valsalva 法による圧負荷があること が報告されている ${ }^{12)}$ 。家族性であっても多くは成人 で発症するため加齢の影響も指摘されている ${ }^{26)}$ 。本 症例では，仕事で重量のある荷物を運搬する機会が 多かったこと, 趣味で懸垂をしていたこと, 加齢な どが発症に関わった可能性がある。

われわれが経験した上半規管裂隙症候群例を提示

し，当科で過去 3 年間に撮影した内耳 CT 画像にお ける上半規管裂隙の頻度について検討した。非常に まれな疾患で，想定して問診と診察・検査を行わな いと見逃す可能性があることを実感した。内耳冠状 断 CT では正確な上半規管裂隙の有無の判断は難し いが，欧米人に比べて本邦での上半規管裂隙の頻度 は低いことが分かった。また，年代間の比較から上 半規管裂隙は先天的なものであることが示唆され た。

\section{文献}

1) Minor LB, Solomon D, Zinreich JS, et al.: Sound- and/or pressure-induced vertigo due to bone dehiscence of the superior semicircular canal. Arch Otolaryngol Head Neck Surg 124: 249-258, 1998

2 ）鈴木光也：Superior canal dehiscence syndrome （上半規管裂隙症候群） その臨床像を中心に. 日耳鼻会報 $114 ： 15-23 ， 2011$

3 ) Naert L, Van de Berg R, Van de Heyning P, et al.: Aggregating the symptoms of superior semicircular canal dehiscence syndrome. Laryngoscope 128: 1932-1938, 2018

4 ）鈴木光也：疾患と病態生理 上半規管裂隙症候 群. JOHNS 33: 1059-1064, 2017

5 ) 内藤 泰, 八木伸也, 伊藤壽一：中耳圧の体平 衡におよぼす影響. Equilibrium Res 45: 364367, 1986

6 ) Nishihara S, Gyo K, Yanagihara N: Transmission of change in the atmospheric pressure of the external ear to the perilymph. Am J Otol 13: 364-368, 1992

7 ）鈴木光也：【検査結果をどう読むか?】平衡覚 領域の検查 Sono-ocular test. JOHNS 29: 1551-
1554,2013

8 ) Grieser BJ, Kleiser L, Obrist D: Identifying Mechanisms Behind the Tullio Phenomenon: a Computational Study Based on First Principles. J Assoc Res Otolaryngol 17: 103-118, 2016

9) Iversen MM, Zhu H, Zhou W, et al.: Sound abnormally stimulates the vestibular system in canal dehiscence syndrome by generating pathological fluid-mechanical waves. Sci Rep 8: 10257, 2018

10) Chien WW, Janky K, Minor LB, et al.: Superior canal dehiscence size: multivariate assessment of clinical impact. Otol Neurotol 33: 810-815, 2012

11) Zuniga MG, Janky KL, Nguyen KD, et al.: Ocular versus cervical VEMPs in the diagnosis of superior semicircular canal dehiscence syndrome. Otol Neurotol 34: 121-126, 2013

12) Ward BK, Carey JP, Minor LB: Superior Canal Dehiscence Syndrome: Lessons from the First 20 Years. Front Neurol 8: 177, 2017

13) Silverstein H, Kartush JM, Parnes LS, et al.: Round window reinforcement for superior semicircular canal dehiscence: a retrospective multicenter case series. Am J Otolaryngol 35: 286293, 2014

14) Suzuki M, Okamoto T, Ushio M, et al.: Two cases of Tullio phenomenon in which oval and round window reinforcement surgery was effective. Auris Nasus Larynx 46: 636-640, 2019

15）青木光広, 林 寿光, 西堀丈純, 他 : 上半規管 裂隙症候群の術後聴力経過. Otology Japan 29: 252-257, 2019

16）小池卓二, 和田 仁, 小林俊光, 他：最適中耳 換気チューブ留置法の検討 理論的考察. Audiology Japan 41: 740-745, 1998

17）鈴木光也, 加我君孝, 中村雅子, 他：両側上半 規管裂隙症候群 (superior canal dehiscence syndrome）の 1 症例. 耳鼻・頭頸外科 75 : 23-26, 2003

18) Masaki Y: The prevalence of superior canal dehiscence syndrome as assessed by temporal 
bone computed tomography imaging. Acta OtoLaryngologica 131: 258-262, 2011

19) Williamson RA, Vrabec JT, Coker NJ, et al.: Coronal computed tomography prevalence of superior semicircular canal dehiscence. Otolaryngol Head Neck Surg 129: 481-489, 2003

20) Carey JP, Minor LB, Nager GT: Dehiscence or thinning of bone overlying the superior semicircular canal in a temporal bone survey. Arch Otolaryngol Head Neck Surg 126: 137-147, 2000

21) Nadgir RN, Ozonoff A, Devaiah AK, et al.: Superior semicircular canal dehiscence: congenital or acquired condition? AJNR Am J Neuroradiol 32: 947-949, 2011

22) Klopp-Dutote N, Kolski C, Biet A, et al.: A radiologic and anatomic study of the superior semicircular canal. European Annals of Otorhinolaryngology, Head and Neck Diseases 133: 9194, 2016

23) Meiklejohn DA, Corrales CE, Boldt BM, et al.: Pediatric Semicircular Canal Dehiscence: Radiographic and Histologic Prevalence, With Clinical Correlation. Otol Neurotol 36: 1383-1389, 2015

24) Saxby AJ, Gowdy C, Fandiño M, et al.: Radiological prevalence of superior and posterior semicircular canal dehiscence in children. Int $\mathrm{J}$ Pediatr Otorhinolaryngol 79: 411-418, 2015

25) Sugihara EM, Babu SC, Kitsko DJ, et al.: Incidence of Pediatric Superior Semicircular Canal Dehiscence and Inner Ear Anomalies: A Large Multicenter Review. Otol Neurotol 37: 13701375, 2016

26) Niesten ME, Lookabaugh S, Curtin H, et al.: Familial superior canal dehiscence syndrome. JAMA Otolaryngol Head Neck Surg 140: 363368, 2014

27) Heidenreich KD, Kileny PR, Ahmed S, et al.: Superior Canal Dehiscence Syndrome Affecting 3 Families. JAMA Otolaryngol Head Neck Surg 143: 656-662, 2017

28) Noonan KY, Russo J, Shen J, et al.: CDH 23 Related Hearing Loss: A New Genetic Risk Factor for Semicircular Canal Dehiscence? Otol Neurotol 37: 1583-1588, 2016

29) Crovetto M, Whyte J, Rodriguez OM, et al.: Anatomo-radiological study of the Superior Semicircular Canal Dehiscence Radiological considerations of Superior and Posterior Semicircular Canals. Eur J Radiol 76: 167-172, 2010

利益相反に該当する事項はない。 